\title{
Nem tapintható tüdőgócok drót- és izotópjelölés segítségével történő minimálinvazív mǘtéti eltávolítása
}

\author{
Farkas Attila dr. ${ }^{1,4}$. Kocsis Ákos dr. ${ }^{1,4}$. Andi Judit dr. ${ }^{2}$ \\ Sinkovics István dr. ${ }^{3}$. Agócs László dr. ${ }^{1,4}$ - Mészáros László dr. ${ }^{1,4}$ \\ Török Klára dr. ${ }^{1,4}$. Bogyó Levente dr. ${ }^{1,4}$ - Radecky Péter dr. ${ }^{1,4}$ \\ Ghimessy Áron dr. ${ }^{1,4}$. Gieszer Balázs dr. ${ }^{1,4}$. Lang György dr., ${ }^{4}$ \\ Rényi-Vámos Ferenc dr. ${ }^{1,4,5}$ \\ Országos Onkológiai Intézet, ${ }^{1}$ Mellkassebészeti Osztály, \\ ${ }^{2}$ Radiológiai Diagnosztikai Osztály, ${ }^{3}$ Nukleáris Medicina Osztály, Budapest \\ ${ }^{4}$ Semmelweis Egyetem, Általános Orvostudományi Kar, Mellkassebészeti Klinika, Budapest \\ ${ }^{5}$ Klinische Abteilung für Thoraxchirurgie, Allgemeines Krankenhaus der Stadt Wien, Austria
}

\begin{abstract}
Bevezetés: Napjainkban egyre kisebb méretű tüdőgócok kerülnek felismerésre, melyek esetén az elsődleges választás azok minimálinvazív mútéti technikával történő eltávolítása diagnosztikus és terápiás céllal. Számos előnye mellett a minimálinvazív technika hátránya a tüdő áttapintásának korlátozottsága, a tüdőgócok felkeresése.

Célkitüzés: A probléma megoldására több lehetőség is rendelkezésre áll. Ezek közül kettőt próbáltunk ki párhuzamosan, a drót-, illetve az izotópjelöléssel történő tüdőgóc-lokalizációt.

Anyag és módszer: Az Országos Onkológiai Intézet Mellkassebészeti Osztályán öt betegnél távolítottunk el tüdőgócot minimálinvazív technikával kettős, azaz drót- és izotópjelölés mellett. A tüdőgócok mérete 0,5 és $1,2 \mathrm{~cm}$ között váltakozott. A betegek életkora 44 és 65 év között volt; minden beteg alacsony mútéti rizikójú csoportba tartozott, súlyos társbetegség nélkül.

Eredmények: Minden betegnél sikeresen eltávolításra került a tüdőgóc a kettős jelölés mellett. Jelölés után közvetlenül egy betegnél 2-3 mm-es légmellet észleltünk, mely azonnali beavatkozásra nem szorult, és egy betegnél a drót miatt kiterjedt bevérzés jelent meg a szúrcsatornában. A mútét során, a tüdőkollapszusnál két betegnél a drót kimozdult, egynél pedig az említett kiterjedt bevérzés a mellüregbe került, és diffúz izotópaktivitás jelent meg. Egy betegnél a mútét során drótjelöléses területet reszekálva további izotópaktivitás állt fenn, mert a jelölt tüdőgóc a reszekciós sík alatt volt.

Következtetés: Mind az izotóppal, mind a dróttal történő tüdőgócjelölés segítséget nyújt a nem tapintható tüdőgócok minimálinvazív technikával történő eltávolításában. Kezdeti tapasztalataink alapján azonban az izotópos jelölés esetén a tüdőgóc mélységi megítélése pontosabb, és nem kell a drótkimozdulással járó kellemetlenségre számítani. Ugyanakkor az infrastrukturális háttér, illetve a mútéti időpont tervezése az izotópbeadás esetében nagyobb kihívást jelent, szemben a drótjelöléssel.
\end{abstract}

Orv Hetil. 2018; 159(34): 1399-1404.

Kulcsszavak: mellkassebészet, VATS, minimálinvazív, izotópjelölés, drótjelölés

Minimally invasive resection of nonpalpable pulmonary nodules after wire- and isotope-guided localization

Introduction: Nowadays ever smaller, sub-centimetre lung nodules are screened and diagnosed. For these, minimally invasive resection is strongly recommended both with diagnostic and therapeutic purpose.

Aim: Despite many advantages of minimally invasive thoracic surgery, thorough palpation of the lung lobes and thus the localization of lung nodules are still limited. There are several options to solve this problem. From the possibilities we have chosen and tried wire- and isotope-guided lung nodule localization.

Materials and methods: In 2017, at the Thoracic Surgery Department of the National Institute of Oncology we performed wire- and isotope-guided minimally invasive pulmonary nodule resection in five patients. The diameter of the 
lung nodules was between 0.5 and $1.2 \mathrm{~cm}$. The age of the patients was between 44 and 65 years and none of them had severe comorbidities, which meant low risk for complications.

Results: We successfully performed the minimally invasive atypical resection in all cases. After the wire and isotope placement we found a $2-3 \mathrm{~mm}$ pneumothorax in one patient that did not need urgent drainage. In another patient we found that high amount of intraparenchymal bleeding surrounded the channel of the wire. During the operation, two wires were displaced when the lung collapsed, and in another case the mentioned bleeding got into the thoracic cavity and made it difficult to detect the nodule. In one case we resected the wire-guided lung tissue, but the isotopeguided lung nodule was below the resection line.

Conclusion: Both techniques could help to localize the non-palpable lung nodules. Based on our initial experiences, the isotope-guided method provides more details to estimate the exact depth of the nodule from the visceral surface of the pleura and we can avoid the unpleasantness of wire displacement. On the other hand, the production of the isotope requires a more developed infrastructure and the exact timing of the operation after the isotope injection is more strict.

Keywords: thoracic surgery, VATS, minimally invasive, isotope-guided localization, wire-guided localization

Farkas A, Kocsis Á, Andi J, Sinkovics I, Agócs L, Mészáros L, Török K, Bogyó L, Radecky P, Ghimessy Á, Gieszer B, Lang Gy, Rényi-Vámos F. [Minimally invasive resection of nonpalpable pulmonary nodules after wire- and isotopeguided localization]. Orv Hetil. 2018; 159(34): 1399-1404.

(Beérkezett: 2018. április 4.; elfogadva: 2018. április 29.)

\section{Rövidítések}

ASA II = (American Society of Anesthesiologists grade II $)$ az Amerikai Aneszteziológiai Társaság szerinti II. stádium; CT = (computed tomography) komputertomográfia; ECOG $0=$ (Eastern Cooperative Oncology Group Performance Status 0) Keleti Kooperatív Onkológiai Csoport 0. teljesítőképességi statusa; $\mathrm{FEV}_{1}=$ (forced vital capacity in 1 second) az első másodpercre eső erőltetett kilégzési térfogat; $\mathrm{FVC}=($ forced vital capacity) erőltetett kilégzési vitálkapacitás; $\mathrm{GGO}=$ (ground-glass opacity) tejüvegszerü homály; VATS = (video-assisted thoracoscopic surgery) videotorakoszkópos mútét

\section{Háttér}

Magyarország Európában évek óta élen áll a tüdőrák okozta halálozásban [1]. A megelőzés fontos eleme a rizikócsoportok hatékony szűrése és a betegség minél korábbi stádiumban való felismerése, aminek jelenleg a leghatékonyabb módszere a low-dose (alacsony dózisú) CT-vel történő szűrés. A „National Lung Screening Trial" vizsgálat óta ismert, hogy szemben a hagyományos mellkas-röntgenfelvétellel, a low-dose CT nagyon korai, szubcentiméteres elváltozások kimutatására alkalmas, így jelentősen képes csökkenteni a tüdőrák okozta mortalitást [2].

Korai stádiumú tüdőrák esetén az elsődleges választás a daganat anatómiai reszekcióval történő mütéti eltávolítása, minimálinvazív (video-assisted thoracoscopic surgery - VATS) mútéti technikával (1. ábra), annak számos előnye miatt: kisebb mútéti fájdalom, rövidebb kórházi tartózkodás, a kemoterápia gyorsabb megkezdésének lehetősége, csökkent citokin-válaszreakció [3].

A daganatos betegek kivizsgálása, szoros kontrollja, utánkövetése során a mellkas-CT-felvételen már kismé- retü áttétek is felismerésre kerülnek. Szoliter tumorok - mint colorectalis [4], emlő- [5], vese- [6], fej-nyaki [7] daganatok és sarcomák [8], tüdő áttétei - esetén is hatékony kezelési forma azok mütéti eltávolítása, ami növeli a betegek túlélését. Szintén elsődlegesen VATS-technikával történő eltávolításuk javasolt, általában atípusos, nem anatómiai reszekcióval [9].

A gyakorlatban ugyanakkor sokszor bizonytalan eredetű tüdőgócok kerülnek felismerésre, melyek dignitása kérdéses. Ezen elváltozások mind diagnosztikus, mind terápiás céllal történő eltávolítása is minimálinvazív technikával javasolt [10].

$\mathrm{Az}$ említett példákon látszik, hogy míg egyre kisebb méretű elváltozások kerülnek felismerésre, azok VATStechnikával történő eltávolítása szintén előtérbe került az elmúlt években. A VATS-mútétek segéd-, vagy úgynevezett „utility” metszés és két vagy egy segédport segítségével történnek, úgynevezett elülső behatolásból (anterior approach). A mütét során a musculus latissimus dorsi szélétől körülbelül $5 \mathrm{~cm}$-es metszést ejtünk a 4 . bordaközben; egy port az elülső axillaris vonalban, három port esetén további egy pedig a scapularis vonalban, a rekesz felett kerül bevezetésre [11, 12]. Később jelentek meg az egy utility metszésen keresztül úgynevezett uni- vagy singleport technikával történő kisebb VATSmútétek [13], majd 2011-ben Diego Gonzalez profeszszor révén először jelent meg cikk az uniportal VATStechnikával végzett anatómiai reszekcióról [14]. Bármely VATS-technikáról legyen is szó, annak sajátossága számos előnye mellett, hogy mivel kisméretű, pár centiméteres metszéseken keresztül operál a sebész, ez megnehezíti a célterület kézzel történő áttapintását, ezáltal a nem egyértelmûen látható tüdőgócok hagyományos módon történő lokalizációját. 


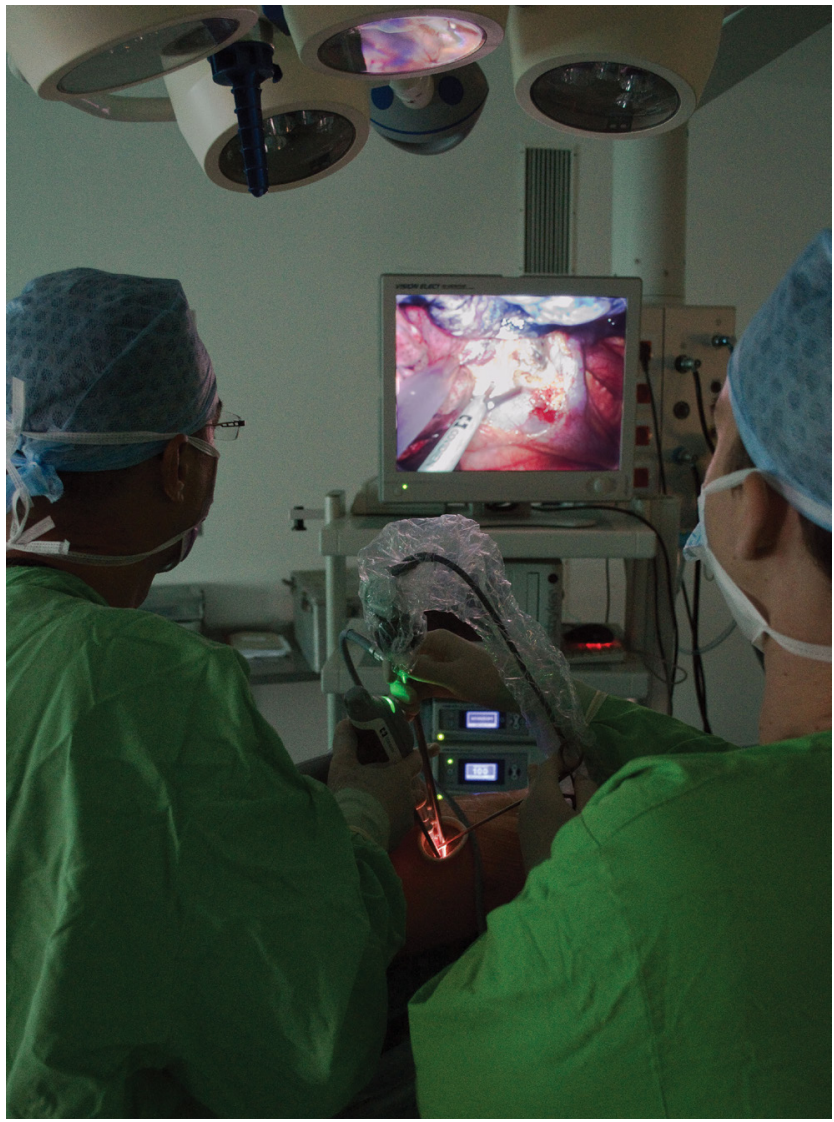

1. ábra

| Minimálinvazív videotorakoszkópos (VATS) mútét

A probléma megoldására az elmúlt években több lehetőség is megjelent. Nem invazív lehetőség az ultrahanggal, a mütét során történő lokalizáció, melynek szövődményrátája alacsony, azonban a mélyen lévő elváltozások, tejüvegszerú homályok (ground-glass opacity - GGO), illetve emphysemás tüdőben lévő gócok kimutatása nehéz vagy nem lehetséges [15].

Percutan, mütét előtti jelölési lehetőségek, hogy CTvezérléssel valamilyen eszközt - drótot vagy speciális anyagot, mint technéciumizotóppal $\left({ }^{99 \mathrm{~m}} \mathrm{Tc}\right)$ jelzett makroaggregált albumint - juttatnak a góc közelébe, megkönnyítve a mútét alatti felkeresést. Tekintettel arra, hogy invazív módon, a mellkasfalon keresztül történik a jelölés, szövődményként felléphet a leggyakrabban légmell és pulmonalis bevérzés, ritkán vérköpés vagy légem- bolia [15-17]. Szövődményekkel és a mütét szervezésével kapcsolatban további technikai probléma, hogy általában külön helyiségben történik a góc jelölése és az operáció, ami megnehezíti egyes szövődmények azonnali, akár a mûtéttel egyidejű ellátását. Kiterjedt légmell esetén a legtöbbször a mellkasi drenázsra a radiológiai osztályon kerül sor, azonban ha a mútőben történik a jelölés, magával a mútét megkezdésével ellátható a szövődmény. A hibrid mútők megjelenésével napjainkban ez a lehetőség is rendelkezésre áll. Ezekben a CT-vel felszerelt, modern kialakítású mútőkben egy helyiségben zajlik a tüdőgóc CT-vezérelt jelölése (akár már altatott betegnél) és maga a mütét [18].

További lehetőség szintén CT-vezérléssel vagy bronchoszkóp segítségével a légutak felől bejuttatni a góc közelébe valamilyen festéket, mely kijelöli a reszekálandó területet $[19,20]$.

Mi ezek közül két technikai lehetőséget próbáltunk ki párhuzamosan betegeinknél, a drót-, illetve az izotópjelöléssel történő tüdőgóc-lokalizációt. Ezen technikák kezdeti tapasztalatairól és eredményeirôl számolunk be.

\section{Anyag és módszer}

Az Országos Onkológiai Intézet Mellkassebészeti Osztályán 2017. 03. 29. és 2017. 12. 19. között 5 betegnél távolítottunk el tüdőgócot kettős, azaz drót- és izotópjelölés mellett, minimálinvazív mútéti technikával.

Egy nő és négy férfi beteget operáltunk; az átlagéletkor 58,6 év volt, és minden beteg ASA II, ECOG 0 stádiumú volt a mûtét elvégzésekor. Tekintettel az irodalomból ismert jelöléskor fellépő potenciális légmellveszélyre, a betegszelekciónál a légzésfunkciós értékeket figyelembe vettük, minden beteg $80 \%$-ot meghaladó FVC és 70\%-ot meghaladó $\mathrm{FEV}_{1}$ légzésfunkciós értékkel rendelkezett. Egy betegnél (2/A ábra) neoadjuváns kemoterápiát követően residualis tüdőtumor eltávolítása mellett döntöttünk, azonban tekintettel a súlyosan emphysemás, degenerált tüdőre, atípusos reszekciót terveztünk, anatómiai reszekció helyett. Két betegnél $(2 / B$ és 2/C ábra) ismert tumoros előzmény mellett tüdőáttétek, további két betegnél pedig ismeretlen eredetü tüdőgócok miatt döntöttünk a mútét mellett $(2 / D$ és $2 / E$ ábra). A legkisebb jelölt tüdőgóc $0,5 \mathrm{~cm}$, míg a legna-

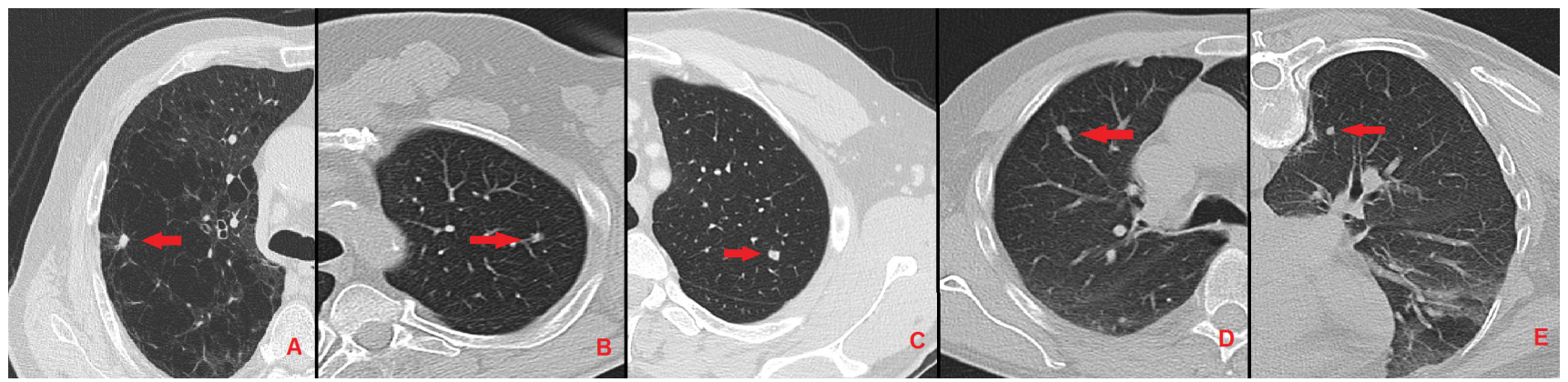

2. ábra |A jelölt tüdőgócok CT-képe 
1. táblázat | Beteganyag

\begin{tabular}{llllllllll}
\hline & Életkor & ASA & ECOG & FVC & FVC $\%$ & FEV $_{1}$ & FEV $_{1} \%$ & Jelöléskor szövődmény & A tüdőgóc mérete \\
\hline l. beteg & 64 & II & 0 & 3,81 & 98 & 2,99 & 92 & Nem & $0,7 \times 0,6 \times 0,5 \mathrm{~cm}$ \\
\hline 2. beteg & 63 & II & 0 & 3,25 & 83 & 2,49 & 81 & $2-3 \mathrm{~mm}$-s légmell & $1 \times 0,5 \times 0,5 \mathrm{~cm}$ \\
\hline 3. beteg & 44 & II & 0 & 4,5 & 92 & 4,1 & 103 & Kiterjedt bevérzés & $0,5 \times 0,7 \times 0,5 \mathrm{~cm}$ \\
\hline 4. beteg & 65 & II & 0 & 4,16 & 96 & 2,3 & 70 & Nem & $1,2 \times 0,7 \times 0,7 \mathrm{~cm}$ \\
\hline 5. beteg & 57 & II & 0 & 4,37 & 97 & 3,48 & 94 & Nem & $0,5 \times 0,5 \times 0,5 \mathrm{~cm}$ \\
\hline
\end{tabular}

ASA II = Amerikai Aneszteziológiai Társaság II. stádium; ECOG $0=$ Eastern Cooperative Oncology Group Performance Status $0 ; \mathrm{FEV}_{1}=\mathrm{első}^{\circ}$ másodpercre eső erőltetett kilégzési térfogat; $\mathrm{FEV}_{1} \%$ = első másodpercre eső erőltetett kilégzési térfogat normál értékhez viszonyított százalékos értéke; $\mathrm{FVC}$ = erőltetett kilégzési vitálkapacitás; $\mathrm{FVC} \%$ = erőltetett kilégzési vitálkapacitás normál értékhez viszonyított százalékos értéke

gyobb $1,2 \mathrm{~cm}$ átmérôjú volt. Az átlagos távolság a visceralis pleurától $1,55 \mathrm{~cm}$ volt (1. táblázat).

A betegek tüdőgócait közvetlenül a mútét elő́tt mellkas-CT-vezérléssel, 0,2 ml, $20 \mathrm{MBq}$ technéciumizotóppal $\left({ }^{99 \mathrm{~m} T c}\right)$ jelzett makroaggregált albuminnal $(3 / A$ ábra), majd egy a mammográfiás jelölésnél használatos DuaLok $^{\circledR}$ (Bard Biopsy Systems, Tempe, AZ, Egyesült Államok) dróttal jelöltük meg ( $3 / B$ ábra). A drótjelölés végén a mellkasból kilógó drót nagy részét levágtuk, a többi $4-5 \mathrm{~cm}$-es szakaszt rögzítésként kiragasztottuk a mellkasfalhoz.

A mûtéteket általános anesztézia, szelektív intubáció és féloldali lélegeztetés mellett, oldalfekvésben lévő betegeken, VATS uniportal technikával végeztük. A mútét során folyamatosan kettős kontrollt alkalmaztunk. A drót jelölte azt a pontot, amely alatt a CT-vezérelt jelöléskor rögzítettük, hogy milyen mélyen fekszik a tüdő-
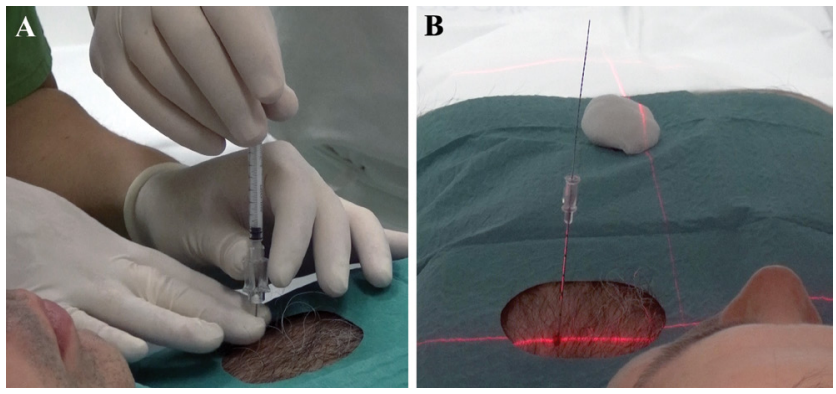

3. ábra

A) Izotópos jelölés, B) drótjelölés

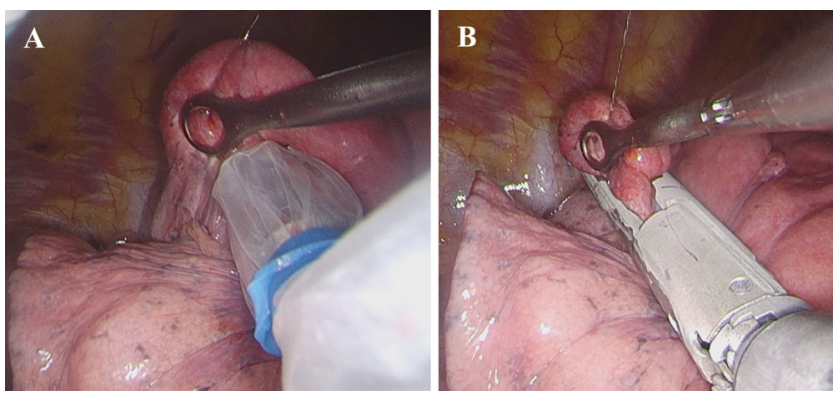

4. ábra

A) Izotóppal kontrolláljuk a mélységet, B) atípusos reszekció endoszkópos varrógéppel góc. A reszekció során azonban a drót alját nem láttuk, mélységi megítélésére gamma-szondát használtunk $(4 / \mathrm{A}$ $a ́ b r a)$. A jelölt területet endoszkópos tüdővarró géppel, atípusos reszekcióval eltávolítottuk (4/B ábra). A reszekálandó terület csúcsaktivitásához képest, ha a reszekált terület alatt nem mértünk érdemi aktivitást, akkor feltételeztük komplettnek a reszekciót. A tüdőgóc-eltávolítás után légáteresztést nem tapasztaltunk, a utility metszésen keresztül visszahagyott dréncső mellett zártuk a mútéti sebet.

\section{Eredmények}

Közvetlenül a drótjelölés után az egyik betegnél 2-3 mm-es légmellet észleltünk, mely 15 perc elteltével nem nőtt, a beteg végig panaszmentes volt, ezért az azonnali beavatkozástól, mellkasi drenázstól eltekintettünk. Egy betegnél a dróthüvely eltávolítása után kiterjedt bevérzés jelent meg, a szúrcsatornának megfelelően. Fontos megemlíteni, hogy ebben az esetben technikai okok miatt a drót nem a lehető legrövidebb útvonalon került bevezetésre. Abban az esetben ugyanis a bal felső és alsó tüdőlebenyek közti fissurán keresztül vezetett volna a drót útja, potenciálisan megsértve az ott futó arteria pulmonalis basalis részét. Mivel a szúrás elölről történt, hosszú szúrcsatorna keletkezett, mely a mélységi megítélést nem tette lehetôvé, és kiterjedt bevérzést okozott. A drótjelölés a betegek szállítása és fektetése során nem mozdult ki egyik alkalommal sem.

A mûtét során két betegnél a drót kimozdult a tüdőkollapszus során, ezért föként a beadott izotóp segített a lokalizációban. Egy betegnél az említett kiterjedt bevérzés a mellüregbe került, és diffúz izotópaktivitás jelent meg, mely megnehezítette a tüdőgóc izotópos lokalizációját.

Egy betegnél a mútét során drótjelöléses területet reszekálva további izotópaktivitás állt fenn, a varratsor alatt ezért rereszekció mellett döntöttünk, és a rereszekált tüdőrész tartalmazta az eltávolításra szánt tüdőgócot.

Minden betegnél sikeresen, az épen került eltávolításra uniportal VATS atípusos reszekcióval a nem tapintható tüdőgóc. A neoadjuváns kezelést követően a súlyosan 
emphysemás tüdőből eltávolított ismert tüdőtumor esetén a végleges szövettan nem állapított meg viabilis tumort. Egy betegnél vese-, egy betegnél pedig vastagbéltumor-áttét került eltávolításra. A két ismeretlen eredetü tüdőgóc esetén pedig hiperszenzitív pneumonitis, illetve granulomatosus gyulladás igazolódott; az utóbbi hátterében tbc-baktérium nem került kimutatásra.

Három betegnél egyszeres VATS atípusos reszekció történt, közülük két betegnél az első napon eltávolítottuk a mellkasi csövet, és a második napon hazabocsátottuk őket. A harmadik, súlyosan emphysemás tüdő mellett operált betegnél a légáteresztés miatt az ötödik napon tudtuk eltávolítani a mellkasi csövet, és a hatodik napon bocsátottuk otthonába. Egy betegnél a jelölt tüdőgóc mellett azonos oldalon több gócot is eltávolítottunk, azaz többszörös VATS atípusos reszekciót végeztünk. Légáteresztés miatt a negyedik napon engedtük haza Heimlich-szelephez csatlakoztatott mellkasi drénnel, majd a kontroll során, a nyolcadik napon távolítottuk el mellkasi drénjét. Egy betegnél a jelölt góc mellett kétoldali VATS atípusos reszekcióval további metastasectomiát végeztünk, nála az első napon eltávolítottuk mellkasi drénjeit, és a harmadik napon bocsátottuk otthonába. Késői szövődmény egyik betegnél sem jelentkezett.

\section{Megbeszélés}

Hála a modern eljárásoknak, egyre kisebb méretű tüdőgócok kerülnek felismerésre, melyek eltávolítása kihívást jelent a mellkassebész számára. A nemzetközi közlemények alapján mind az izotóppal, mind a dróttal történő jelölés segítséget nyújthat, lehetővé téve a nem tapintható tüdőgócok minimálinvazív technikával történő eltávolítását.

Ichinose és mtsai közleményében 500 tüdőgóc dróttal történő jelölését követően 49\%-ban légmell, 7,4\%-ban pulmonalis bevérzés, 2,2\%-ban vérköpés és 0,2\%-ban szisztémás légembolia jelent meg. Drótkimozdulás 0,4\%-ban fordult elő [15]. Seo és mtsai 181, dróttal jelölt beteg adatainak feldolgozása során $40 \%$-ban légmellet, 36\%-ban pulmonalis bevérzést és 4,5\%-ban drótkimozdulást találtak. Eredményeik alapján a sikeres jelölés egyértelmúen összefügg a pleurafelszín és a drót végének távolságával, továbbá befolyásolja a tüdőgócok elhelyezkedése és szolid komponensének mértéke [17]. Ezzel szemben Chu és mtsai közleményében éppen a nem szolid komponensû tüdőgócok drótjelölésének sikerességét hangsúlyozzák [21]. Hanauer és mtsai közleményében 187 tüdőgóc dróttal történő jelölését követően 38\%-ban légmell, 5,9\%-ban pulmonalis bevérzés jelent meg. Vérköpés, illetve légembolia az ő beteganyagukban nem, drótkimozdulás 3,7\%-ban fordult elő [16]. Drótjelölés során, hasonlóan az irodalomban leírtakhoz, nálunk is megjelent intraparenchymalis bevérzés, légmell, illetve drótkimozdulás a mütét során. A jelölést követően vérköpés vagy légembolia nem jelent meg.
Davini és mtsai 175 beteg tüdőgóca esetén végeztek izotóppal történő jelölést. A jelölések után 7,4\%-ban lépett fel légmell, egyéb szövődmény nem volt. Mindegyik jelölést sikeres VATS-tüdőgóceltávolítás követett [22]. Galetta és mtsai 112 betegnél végeztek tüdőgócjelölést, 29,4\%-ban a jelölést követően légmell, 20,5\%-ban pulmonalis bevérzés és $0,9 \%$-ban allergiás reakció lépett fel a beadott izotóppal szemben. 11 esetben volt izotóp-extravasatio a mellüreg felé, melyek közül mindössze 2 esetben volt emiatt sikertelen a tüdőgóc detektálása [23]. Bertolaccini és mtsai 19 nem tapintható tüdőgócjelölést végeztek izotóppal, és 5 esetben légmell, 2 esetben kisebb mértékü pulmonalis bevérzés jelentkezett. l esetben történt izotóp-extravasatio a mellüregbe, mely nehézséget a mütét során nem okozott, minden tüdőgóc sikeresen lett eltávolítva [24]. Saját beteganyagunkban komplikációként egyszer lépett fel extravasatio a mellüreg felé, mely diffúz aktivitásként megnehezítette a tüdőgóc elkülönítését. Az extravasatum eltávolítása után azonban egyértelmúen lokalizálható volt a tüdőgóc. Egyéb szövődmény az izotópos jelöléssel kapcsolatban nem lépett fel.

Gonfiotti és mtsai 25-25 beteg drót-, illetve izotópjelölésének összehasonlítását követően jutottak arra a megállapításra, hogy bár mindkét technika eredményes a nem tapintható tüdőgócok lokalizációjában, az izotópjelölés kevesebb szövődménnyel és hibalehetőséggel jár [25].

\section{Következtetés}

Fontos hangsúlyoznunk, hogy kezdeti eredményeinket, tapasztalatainkat kisszámú drót-, illetve izotópos tüdőgócjelölés kapcsán szereztük, ezért a végleges következtetések levonásához nagyobb beteganyag bevonása szükséges.

Saját tapasztalataink alapján általánosságban elmondható, hogy a drótjelölés a mélységi lokalizációban kevesebb segítséget nyújt az izotópjelöléssel szemben, és a nemzetközi irodalommal összhangban több szövődménnyel és technikai hibalehetőséggel jár. Ugyanakkor az izotóp elóállítása és használata jelentős infrastrukturális hátteret igényel, továbbá a jelölés során kulcsfontosságú a beadandó izotóp mennyiségének, beadási idejének pontos meghatározása és a jelölés utáni közvetlen műtét elvégzése.

Hasonló módszerek bevezetését olyan videotorakoszkópos mútétekben jártas mellkassebészeti osztályoknak ajánljuk, ahol rendelkezésre áll a megfelelő invazív radiológiai, illetve nukleáris medicinai háttér.

Anyagi támogatás: A közlemény megírása anyagi támogatásban nem részesült.

Szerzői munkamegosztás: Az irodalomkutatásban, a kézirat összeállításában és megírásában a szerzők egyenlő mértékben tevékenykedtek. A mütétekben F. A., K. Á., 
A. L., M. L., T. K., B. L., R. P., G. Á., G. B., L. Gy., R.-V. F. vett részt. A CT-vezérelt drótjelöléseket A. J., az izotópjelöléseket $S$. I. végezte. A cikk végleges változatát valamennyi szerző elolvasta és jóváhagyta.

Érdekeltségek: A szerzőknek a cikk megírásával kapcsolatban pénzügyi vagy személyes érdekeltségük nem volt.

\section{Irodalom}

[1] Moldvay J, Rokszin G, Abonyi-Tóth Z, et al. Lung cancer drug therapy in Hungary - 3-year experience. Onco Targets Ther. 2015; 8: 1031-1038

[2] Aberle DR, Adams AM, Berg CD, et al. Reduced lung-cancer mortality with low-dose computed tomographic screening. N Engl J Med. 2011; 365: 395-409.

[3] Nagahiro I, Andou A, Aoe M, et al. Pulmonary function, postoperative pain, and serum cytokine level after lobectomy: a comparison of VATS and conventional procedure. Ann Thorac Surg. 2001; 72: 362-365

[4] Hirai F, Kinoshita I, Matsubara T, et al. Which primary organ is most suitable for performing pulmonary metastasectomy? Anticancer Res. 2018; 38: 1041-1045.

[5] Macherey S, Mallmann P, Malter W, et al. Lung metastasectomy for pulmonary metastatic breast carcinoma. Geburtshilfe Frauenheilkd. 2017; 77: 645-650.

[6] Friedel G, Hürtgen M, Penzenstadler M, et al. Resection of pulmonary metastases from renal cell carcinoma. Anticancer Res. 1999; 19(2c): 1593-1596

[7] Subramaniam NR, Reddy R, Balasubramanian D, et al. Is pulmonary metastasectomy beneficial in head and neck squamous cell carcinoma? A review of literature. Indian J Cancer 2017; 54: 2-5.

[8] Kim S, Ott HC, Wright CD, et al. Pulmonary resection of metastatic sarcoma: prognostic factors associated with improved outcomes. Ann Thorac Surg. 2011; 92: 1780-1786. Discussion: 1786-1787.

[9] Carballo M, Maish MS, Jaroszewski DE, et al. Video-assisted thoracic surgery (VATS) as a safe alternative for the resection of pulmonary metastases: a retrospective cohort study. J Cardiothorac Surg. 2009; 4: 13.

[10] Cardillo G, Regal M, Sera F, et al. Videothoracoscopic management of the solitary pulmonary nodule: a single-institution study on 429 cases. Ann Thorac Surg. 2003; 75: 1607-1611. Discussion: 1611-1612.

[11] Hansen HJ, Petersen RH. Video-assisted thoracoscopic lobectomy using a standardized three-port anterior approach - the Copenhagen experience. Ann Cardiothorac Surg. 2012; 1: 7076.
[12] Onaitis MW, Petersen RP, Balderson SS, et al. Thoracoscopic lobectomy is a safe and versatile procedure: experience with 500 consecutive patients. Ann Surg. 2006; 244: 420-425.

[13] Rocco G, Martin-Ucar A, Passera E. Uniportal VATS wedge pulmonary resections. Ann Thorac Surg. 2004; 77: 726-728.

[14] Gonzalez D, Paradela M, Garcia J, et al. Single-port video-assisted thoracoscopic lobectomy. Interact Cardiovasc Thorac Surg. 2011; 12: 514-515.

[15] Ichinose J, Kohno T, Fujimori S, et al. Efficacy and complications of computed tomography-guided hook wire localization. Ann Thorac Surg. 2013; 96: 1203-1208.

[16] Hanauer M, Perentes JY, Krueger T, et al. Pre-operative localization of solitary pulmonary nodules with computed tomographyguided hook wire: report of 181 patients. J Cardiothorac Surg. 2016; 11: 5 .

[17] Seo JM, Lee HY, Kim HK, et al. Factors determining successful computed tomography-guided localization of lung nodules. J Thorac Cardiovasc Surg. 2012; 143: 809-814.

[18] Kostrzewa M, Kara K, Rathmann N, et al. Computed tomography-assisted thoracoscopic surgery: a novel, innovative approach in patients with deep intrapulmonary lesions of unknown malignant status. Invest Radiol. 2017; 52: 374-380.

[19] Endo M, Kotani Y, Satouchi M, et al. CT fluoroscopy-guided bronchoscopic dye marking for resection of small peripheral pulmonary nodules. Chest 2004; 125: 1747-1752.

[20] Yang SM, Ko WC, Lin MW, et al. Image-guided thoracoscopic surgery with dye localization in a hybrid operating room. J Thorac Dis. 2016; 8(Suppl 9): S681-S689.

[21] Chu X, Hou X, Zhang L, et al. Clinical study of intra-operative computed tomography guided localization with a hook-wire system for small ground glass opacities in minimally invasive resection. Zhongguo Fei Ai Za Zhi 2014; 17: 845-849.

[22] Davini F, Ricciardi S, Zirafa CC, et al. Treatment of pulmonary nodule: from VATS to RATS. J Vis Surg. 2018; 4: 36.

[23] Galetta D, Bellomi M, Grana C, et al. Radio-guided localization and resection of small or ill-defined pulmonary lesions. Ann Thorac Surg. 2015; 100: 1175-1180.

[24] Bertolaccini L, Terzi A, Spada E, et al. Not palpable? Role of radio-guided video-assisted thoracic surgery for nonpalpable solitary pulmonary nodules. Gen Thorac Cardiovasc Surg. 2012; 60: 280-284.

[25] Gonfiotti A, Davini F, Vaggelli L, et al. Thoracoscopic localization techniques for patients with solitary pulmonary nodule: hookwire versus radio-guided surgery. Eur J Cardiothorac Surg. 2007; 32: 843-847.

(Farkas Attila dr., Budapest, Ráth Gy. u. 7-9., 1122 e-mail: attilahungary87@gmail.com)

A cikk a Creative Commons Attribution-NonCommercial 4.0 International License (https://creativecommons.org/licenses/by-nc/4.0) feltételei szerint publikált Open Access közlemény, melynek szellemében a cikk nem kereskedelmi célból bármilyen médiumban szabadon felhasználható, megosztható és újraközölhető, feltéve, hogy az eredeti szerző és a közlés helye, illetve a CC License linkje és az esetlegesen végrehajtott módosítások feltüntetésre kerülnek. 